\title{
Molecular and Phenotypic Diversity of Common Bean Landraces from Nicaragua
}

\author{
Oscar J. Gómez, Matthew W. Blair, Bodil E. Frankow-Lindberg,* and Urban Gullberg
}

\section{ABSTRACT}

The knowledge and understanding of the genetic structure of bean (Phaseolus vulgaris $\mathbf{L}$.) landraces is important for the implementation of measures addressed to their management and conservation. The purpose of this paper was to study the pattern of genetic variation in nine red-seeded landraces currently grown by farmers with molecular and phenotypic markers. Twelve individuals per landrace were genotyped with seven bean microsatellite markers. Fourteen phenotypic traits were additionally measured in a field study in two localities. An important finding of this study was the complementary information obtained with both kinds of markers. Most of the variation at the molecular level was explained by differences within or among landraces but not among agroecological zones, while at the phenotypic level most of the variation was attributed to differences among agroecological zones. This suggests that molecular differentiation of landraces [coancestry coefficient $\left(F_{\text {ST }}\right)=0.34$ ] was due to founder effect while phenotypic differentiation was due to the effect of adaptation. Within landraces, an average of 5.7 alleles per locus was identified, with a range from 2 to 13 alleles depending on the individual microsatellite. The average gene diversity within landraces and total gene diversity was 0.35 and 0.51 , respectively. Implications of the findings in planning future collections of genetic resources of common bean as well as the effect of sites on uncovering adaptive traits are also discussed.

$\mathrm{T}$ HE COMMON BEAN, over a period of at least 7000 to $8000 \mathrm{yr}$, has been domesticated and evolved from a wild vining plant distributed in the highlands of Middle America and the Andes into a major leguminous food crop, grown worldwide in a broad range of environments and cropping systems (Gepts and Debouck, 1991). The cultivated bean is a morphologically diverse crop with large variation in growth habit, pigmentation, pod, seed, and phenology (Singh et al., 1991). The species is an annual with a predominantly self-pollinating reproductive system. Typical outcrossing rates are under 5\% (Graham and Ranalli, 1997); however, higher levels have also been reported (Gepts, 1993; Ibarra-Perez et al., 1997).

Bean production is performed in all regions of Nicaragua and occupies $>60 \%$ of the total agricultural area (Llano et al., 1998). Seed color and growth habit are the most variable traits between Nicaraguan landraces. Farmers predominantly grow small red-seeded beans, although they also have landraces that have brown- or cream-colored seed.

O.J. Gómez, National Agrarian Univ., North Highway km 12.5, Managua, Nicaragua; M.W. Blair, Int. Center for Tropical Agriculture (CIAT), Bean Program, A.A. 6713, Cali, Colombia; B.E. FrankowLindberg, Dep. of Ecology and Crop Production Sci., P.O. Box 7043, and U. Gullberg, Dep. of Plant Biology, P.O. Box 7080, Swedish Univ. of Agricultural Sci., SE-750 07 Uppsala, Sweden. Received 10 July 2003.*Corresponding author (bodil.frankow-lindberg@evp.slu.se).

Published in Crop Sci. 44:1412-1418 (2004).

(c) Crop Science Society of America

677 S. Segoe Rd., Madison, WI 53711 USA
In general, landraces are the most diverse populations of cultivated plants (Frankel et al., 1995). Besides being adapted to their natural and man-made environments, landrace genotypes tend to be co-adapted. Hence, genetic variation within a landrace may be considerable, but is far from random (Qualset et al., 1997). The genetic diversity among and within landraces makes them a valuable resource as potential donors of genes for the development and maintenance of modern crop varieties, and for direct use by farmers (Soleri and Smith, 1995).

Classical methods of estimating diversity among groups of plants have relied chiefly upon morphological characters, which still play a central role in the ANOVA in crop species and their relatives (Newbury and FordLloyd, 1997). However, because of the strong environmental influence on morphological traits, mainly on those of a quantitative nature, new techniques which analyze diversity at biochemical or molecular level have been developed (Karp et al., 1997) and successfully applied in evolutionary and diversity studies of different crops (Gepts, 1993; Bretting and Widrlechner, 1995). Molecular techniques are more expensive than most morphological approaches to the study of genetic or species diversity (Newbury and Ford-Lloyd, 1997), and consequently they should be used only where other techniques are less powerful or not feasible (Bisby, 1995). Molecular analyses in conjunction with morphological and agronomic evaluation of germplasm is recommended because these provide complementary information and increase the resolving power of genetic diversity analyses (Singh et al., 1991).

In the context of in situ conservation of landraces, both molecular and morphological marker evaluations are useful for identifying populations for conservation, optimum sites for germplasm collection, and ongoing changes in the pattern of diversity in the course of conservation practices (Newbury and Ford-Lloyd, 1997). Few studies have analyzed the pattern of genetic diversity within landraces (Martin and Adams, 1987a; Briand et al., 1998) as compared with that among landraces held in large ex situ germplasm collections (Singh et al., 1991; Beebe et al., 2000; Islam et al., 2002). The knowledge and understanding of the genetic structure of plant landraces is important since it may serve as a basis for making decisions related to the selection of sites and populations for in situ conservation (Maxted et al., 1997). The above information is also valuable for genebank curators in providing a more secure basis on which sampling strategies (number of plants or seeds per sample and pattern of sampling) can be implemented (Engels and Visser, 2000). In this study we hypothesized that (i) the genetic structure measured is independent of whether molecular or phenotypic markers are used, (ii) there is no genetic differentiation between agroecological zones, (iii) there is no genetic differentiation 
Table 1. Topographic and climatic conditions of the agroecological zones where the common bean landraces were collected.

\begin{tabular}{lccccc}
\hline $\begin{array}{l}\text { Agroecological } \\
\text { zone } \dagger\end{array}$ & Elevation & $\begin{array}{c}\text { Average } \\
\text { temperature }\end{array}$ & $\begin{array}{c}\text { Average } \\
\text { precipitation }\end{array}$ & $\begin{array}{c}\text { Rainfall } \\
\text { period }\end{array}$ & Landrace \\
\hline & masl + & $\mathbf{m}$ & $\mathbf{m m}$ & & \\
B & $\mathbf{7 0 0 - 1 0 0 0}$ & $\mathbf{2 2 - 2 4}$ & $\mathbf{1 6 0 0 - 2 0 0 0}$ & May-November & V16, V22 \\
F & $\mathbf{3 0 0 - 5 0 0}$ & $\mathbf{2 4 - 2 7}$ & $\mathbf{1 2 0 0 - 1 8 0 0}$ & May-October & V29 \\
H & $\mathbf{5 0 0 - 1 0 0 0}$ & $\mathbf{2 2 - 2 5}$ & $\mathbf{1 2 0 0 - 1 6 0 0}$ & May-October & V1, V17 \\
I & $<\mathbf{3 0 0}$ & $\mathbf{2 7 - 2 9}$ & $\mathbf{1 2 0 0 - 1 6 0 0}$ & May-October & V6, V9, V18, V26 \\
\hline
\end{tabular}

$\uparrow$ Letters represent some of the different agroecological zones classified according to climatic and soil characteristics of Nicaraguan territory (more information can be found in Marín, 1990).

$\uparrow$ Meters above sea level.

among landraces within agroecological zones, and finally (iv) phenotypic traits are not affected by the testing site.

\section{MATERIALS AND METHODS}

\section{Plant Material}

Seventeen common bean landraces presently cultivated by farmers were used to study genetic variation at the molecular level. Of these, only nine red-seeded landraces were chosen for the field study. They were collected from different sites spread across four distinct agroecological zones (none close to the experimental site, Table 1). A seed sample of $450 \mathrm{~g}$ was obtained from a local farmer at each site in April and May 1999. All samples were multiplied for one generation to get enough seeds for further experiments during the first cropping season (May-August) in 2000.

\section{Molecular Evaluation}

In the first step, DNA from 12 individuals of the 17 landraces was pooled and tested with 20 microsatellites [J04555, M75856, U18791, X04001, X60000, X61293, X80051, X57022, X04660 (Yu et al., 1999); AG1, BM53, BM98, BM114, GATS11, GATS11b, GATS54, GATS91 (Gaitán-Solís et al., 2002); BM15, BM19 (CIAT, 2002); and BMd36 (Blair et al., 2003)]. The seven most polymorphic markers were chosen for further assays on the full set of individuals. The genomic DNA was extracted from young primary leaves of 4-d-old germinated seedlings according to Dellaporta et al. (1983) and Gonzalez et al. (1995).

\section{PCR Amplification of Microsatellite Loci}

The alleles were amplified in $20-\mu \mathrm{L}$ reaction volumes. The reaction mixtures consisted of $5 \mu \mathrm{L}$ of DNA $\left(10 \mathrm{ng} \mu \mathrm{L}^{-1}\right)$, $0.1 \mu \mathrm{L}$ Taq $\left(5 \mathrm{U} \mu \mathrm{L}^{-1}\right), 0.25 \mu \mathrm{L}$ of each primer, $3 \mu \mathrm{L}$ of dNTPs (4 $\mu M$ each one), and $2 \mu \mathrm{L}$ of buffer $\left[\left(10 x+\mathrm{MgCl}_{2}(15 \mathrm{~m} M)\right]\right.$. The PCR conditions consisted of a hot start of $92^{\circ} \mathrm{C}$ for 5 min, followed by 29 cycles of denaturation at $92^{\circ} \mathrm{C}$ for $1 \mathrm{~min}$, annealing at $60^{\circ} \mathrm{C}$ for $1 \mathrm{~min}$, and extension at $72^{\circ} \mathrm{C}$ for $1 \mathrm{~min}$.
For two microsatellites (GATS54 and BM114), the annealing temperature was reduced to $52^{\circ} \mathrm{C}$. The cycles were followed by a final elongation step at $72^{\circ} \mathrm{C}$ for $7 \mathrm{~min}$. The microsatellite alleles were resolved on silver-stained polyacrylamide gels and sized by comparison to 10- and 25-bp molecular weight standards (Promega). Only bands clearly separated visually were accepted as different alleles.

\section{Statistical Analysis of Molecular Data}

The following indices were used to quantify the amount of genetic diversity within each landrace: number of alleles per locus, observed heterozygosity $\left(\mathrm{H}_{\mathrm{o}}\right)$, and expected heterozygosity $\left(\mathrm{H}_{\mathrm{e}}\right)$. The values for each of these indices were calculated for each landrace per locus combination and across all loci according to Nei (1987). All calculations were realized by the computer programs FSTAT V2.9.3 (Goudet, 2002) and GENEPOP 3.3 (Raymond and Rousset, 2001). The partitioning of variation within and among landraces and agroecological zones was calculated with an AMOVA computed with the program Arlequin (Schneider et al., 2000). Wright's $F$ statistics as well as $99 \%$ confidence intervals of their mean values were calculated according to Weir and Cockerham (1984) with the software Fstat V2.9.3 (Goudet, 2002).

\section{Experimental Sites}

The phenotypic evaluation of the nine landraces was conducted at San Marcos (La Compañia Experimental Station) and San Pedro (in a farmer's field) both in the department of Carazo, Nicaragua. The experiments were performed during the second cropping season (September-December) in 2000. Crop management was similar at both sites. Sowing was done manually in rows. Fertilization consisted of a banded application of $16 \mathrm{~kg} \mathrm{~N}, 22 \mathrm{~kg} \mathrm{P}_{2} \mathrm{O}$, and $31 \mathrm{~kg} \mathrm{~K}_{2} \mathrm{O}$ ha $^{-1}$. Weed control was performed by hand, and plots were maintained pest and disease free until harvest. At San Marcos, soil preparation was done with conventional tillage while at San Pedro, soil preparation was done with oxen. The sites of the experiments are located $40 \mathrm{~km}$ apart from each other and differ in soil and climatic variables (Table 2). The experimental layout was a randomized complete block design with four replicates.

Table 2. Topographic, climatic and soil characteristics of the two experimental field sites.

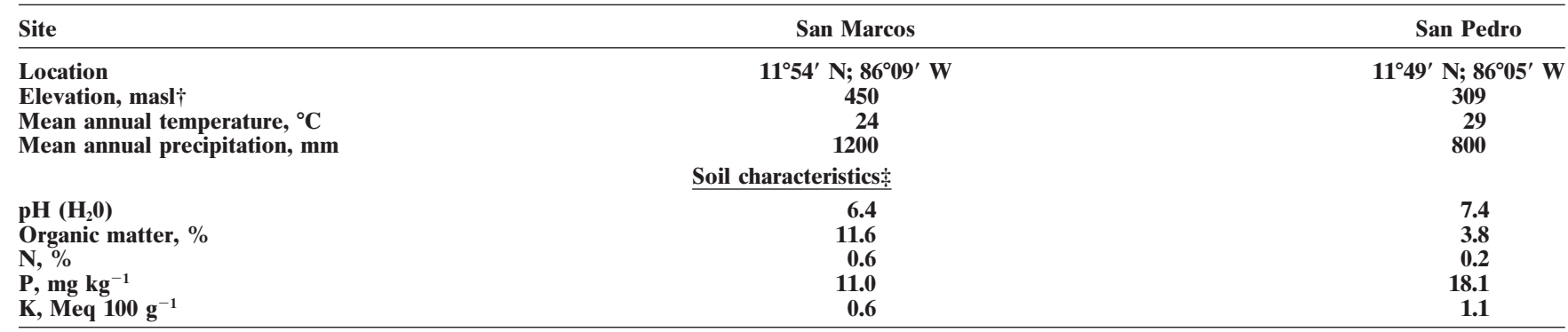

$\dagger$ Meters above sea level.

\$ The analyses were carried out at National Agrarian University, Soil laboratory. 
Table 3. Phenological (P), morphological (M), qualitative (Q), and agronomic (A) traits measured for nine Nicaraguan bean landraces.

\begin{tabular}{|c|c|c|}
\hline Character & Classification & Description \\
\hline Initiation of flowering (DAP) $\dagger$ & $\mathbf{P}$ & $\begin{array}{l}\text { Number of days from sowing until the appearance of the first open flower in any of } \\
\text { the sampled plants }\end{array}$ \\
\hline Days to flowering (DAP) & $\mathbf{P}$ & $\begin{array}{l}\text { Number of days from sowing to the stage when } 50 \% \text { of the sampled plants have } \\
\text { begun to flower }\end{array}$ \\
\hline Physiological maturity (DAP) & $\mathbf{P}$ & $\begin{array}{l}\text { Number of days from sowing until } 50 \% \text { of the sampled plants have changed the color } \\
\text { of their pods }\end{array}$ \\
\hline Stem length (cm) & M & $\begin{array}{l}\text { The distance from the ground surface to the tip of the main guide at flowering. } \\
\text { Sample size: } 10 \text { plants } \text { plot }^{-1}\end{array}$ \\
\hline Leaf surface area $\left(\mathrm{cm}^{2}\right)$ & M & $\begin{array}{l}\text { Area of the terminal leaflet from the trifoliate leaf originating at the fourth node. } \\
\text { Sample size: } 5 \text { leaflets } \text { plot }^{-1}\end{array}$ \\
\hline Pod length, cm & $\mathbf{M}$ & Exterior distance from the pod apex to the peduncle. Sample size: 30 pods plot $^{-1}$ \\
\hline Pod width, $\mathrm{cm}$ & M & $\begin{array}{l}\text { Distance from the right angle to the sutures at the middle of the pod. Sample size: } \\
30 \text { pods }^{-1} \text { plot }^{-1}\end{array}$ \\
\hline Growth habit & $\mathbf{Q}$ & 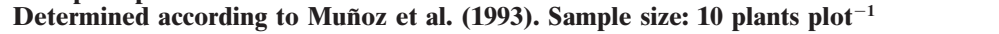 \\
\hline Wing petal color & Q & $\begin{array}{l}\text { Determined in freshly opened flowers according to Muñoz et al. (1993). Sample size: } \\
10 \text { plants plot }{ }^{-1}\end{array}$ \\
\hline Standard petal color & $\mathbf{Q}$ & Same as for color of wings \\
\hline Pods plant $^{-1}$ & A & Average number of fertile pods plant ${ }^{-1}$. Sample size: 10 plants plot $^{-1}$ \\
\hline Seeds pod ${ }^{-1}$ & $\mathbf{A}$ & Average number of seeds pod $^{-1}$. Sample size: 30 pods plot $^{-1}$ \\
\hline 100-seed weight, $g$ & $\mathbf{A}$ & Average 100-seed weight (14\% moisture) \\
\hline Yield per plot, $\mathrm{kg} \mathrm{ha}^{-1}$ & $\mathbf{A}$ & Determined on the basis of the total number of harvested plants plot ${ }^{-1}$ \\
\hline
\end{tabular}

$\dagger$ Days after planting.

The experimental plot consisted of four 4-m-long rows, spaced 0.5 and $0.4 \mathrm{~m}$ apart at San Marcos and San Pedro, respectively, with a plant-to-plant spacing of $0.1 \mathrm{~m}$. Each plot was planted with 160 seeds, which resulted in plant populations of 200000 and 250000 plants ha ${ }^{-1}$ at San Marcos and San Pedro, respectively. These values are within the ranges of commercial planting densities in Nicaragua.

\section{Measurements}

Fourteen agromorphological traits were determined according to Muñoz et al. (1993) (Table 3). Frequencies of each class were calculated for the three qualitative traits, namely, growth habit, wing petal color, and standard petal color. For the analysis of growth habit, a square root transformation $(\sqrt{X+0.5})$ was performed.

\section{Statistical Analysis of Field Data}

Analyses of covariance were performed according to the following model: $\mathrm{Y}_{\mathrm{ijkl}}=\mu+\alpha_{\mathrm{i}}+\beta_{\mathrm{j}(\mathrm{i})}+\gamma_{\mathrm{k}}+\alpha \gamma_{\mathrm{ik}}+\delta_{\mathrm{l}(\mathrm{k})}+$ $\varepsilon_{\mathrm{ijkl}}$, where $\mathrm{Y}_{\mathrm{ijkl}}=$ response, $\mu=$ an overall constant, $\alpha_{\mathrm{i}}=$ the site effect, $\beta_{\mathrm{j}(\mathrm{i})}=$ the block effect nested within site, $\gamma_{\mathrm{k}}=$ the agroecological zone effect, $\alpha \gamma_{\mathrm{ik}}=$ the site by agroecological zone interaction, $\delta_{1(\mathrm{k})}=$ the landrace effect nested within agroecological zone, and $\varepsilon_{\mathrm{ijkl}}=$ the experimental error.

The number of harvested plants was used as a covariable. The ANOVA analyses were performed with the software JMP (SAS Institute, 2000). The mean separation was done by Tukey-Kramer HSD at 5\% level. For the comparison of population frequencies for qualitative traits (wing color, standard color), a Fisher's exact test was used and calculated with the PROC FREQ procedure in the SAS software package, release 6.12 (SAS Institute, 1997).

\section{RESULTS}

\section{Population Differentiation and Genetic Structure}

A strong genetic differentiation was found among the landraces since all three of Wright's $F$ statistics for the pooled set of loci were positive and different from zero. The mean $F_{\text {IS }}$ (inbreeding coefficient) value was high (0.95) with a $99 \%$ confidence interval from 0.88 to 1.0 . Landrace differentiation made $F_{\text {IT }}$ (total inbreeding co- efficient) even higher (0.96). The $F_{\mathrm{ST}}$ value indicates that on average $34 \%$ of the genetic variation was explained by differences among landraces.

The AMOVA analysis showed that the variation attributable to agroecological zones was zero (variance 0 , $3 \mathrm{df} ; P<0.48)$, while $36.5 \%(0.7,5 \mathrm{df}, P<0.001)$ and $63.5 \%(1.1,207 \mathrm{df}, P<0.001)$ of the variation was distributed among landraces within agroecological zone and within landraces, respectively.

\section{Diversity Measures}

An average of 5.7 alleles were identified per microsatellite locus, with a range of 2 to 13 distinct alleles in the full array of individuals per each landrace depending on the individual microsatellite (Table 4). Some of these alleles were unique to an individual landrace as observed for V1 (one and three alleles from the loci BM114 and GATS91, respectively), V17 (one allele, locus BMd36), V-26 (two alleles from the locus GATS91), and V29 (one allele, locus GATS91). The observed and expected heterozygosity values within populations averaged across all loci fluctuated between zero and 0.04 (average $=0.01)$ and from 0.16 to 0.47 (average $=0.35)$, respectively (Table 5). For some loci, specifically J04555 and BM114 and for landraces mainly from the agroecological Zone I, high levels of observed heterozygosity $\left(\mathrm{H}_{\mathrm{o}}\right)$ were detected. The total gene diversity gene diver-

Table 4. Number of alleles detected for seven microsatellite loci assayed across nine bean landraces.

\begin{tabular}{|c|c|c|c|c|c|c|c|c|c|c|}
\hline \multirow{2}{*}{$\begin{array}{l}\text { SSR } \\
\text { locus }\end{array}$} & \multicolumn{9}{|c|}{ Bean landraces } & \multirow[b]{2}{*}{ Total } \\
\hline & V1 & V6 & V9 & V16 & V17 & V18 & V22 & V26 & V29 & \\
\hline & \multicolumn{10}{|c|}{ Number of alleles } \\
\hline AG1 & 2 & 1 & 1 & 2 & 1 & 1 & 1 & 2 & 2 & 2 \\
\hline BM114 & 3 & 3 & 3 & 2 & 2 & 2 & 2 & 3 & 2 & 4 \\
\hline BMd36 & 2 & 1 & 2 & 7 & 5 & 7 & 5 & 3 & 9 & 12 \\
\hline GATS54 & 1 & 1 & 1 & 2 & 2 & 2 & 2 & 2 & 2 & 2 \\
\hline GATS91 & 3 & 3 & 4 & 3 & 5 & 4 & 4 & 3 & 2 & 13 \\
\hline J04555 & 3 & 1 & 1 & 2 & 3 & 5 & 4 & 2 & 4 & 5 \\
\hline X04001 & 2 & 1 & 1 & 2 & 2 & 1 & 1 & 1 & 2 & 2 \\
\hline Mean & 2.3 & 1.6 & 1.9 & 2.9 & 2.9 & 3.1 & 2.7 & 2.3 & 3.3 & 5.7 \\
\hline
\end{tabular}


Table 5. Genetic variation in nine red-seeded common bean landraces assayed with seven microsatellite markers.

\begin{tabular}{|c|c|c|c|c|c|c|c|c|c|c|c|c|c|c|c|c|c|}
\hline \multirow{2}{*}{$\begin{array}{l}\text { Agroecological } \\
\text { zone }\end{array}$} & \multirow[b]{2}{*}{ Landrace } & \multicolumn{2}{|c|}{ AG1 } & \multicolumn{2}{|c|}{ BM114 } & \multicolumn{2}{|c|}{ BMd36 } & \multicolumn{2}{|c|}{ GATS54 } & \multicolumn{2}{|c|}{ GATS91 } & \multicolumn{2}{|c|}{ J04555 } & \multicolumn{2}{|c|}{ X04001 } & \multirow{2}{*}{\multicolumn{2}{|c|}{$\begin{array}{l}\text { Mean per landrace } \\
\text { across loci }\end{array}$}} \\
\hline & & $\mathbf{H}_{0} \dagger$ & $\mathbf{H}_{\mathrm{e}} \ddagger$ & $\mathbf{H}_{0}$ & $\mathbf{H}_{\mathrm{e}}$ & $\mathbf{H}_{0}$ & $\mathbf{H}_{\mathbf{e}}$ & $\mathbf{H}_{0}$ & $\mathbf{H}_{\mathrm{e}}$ & $\mathbf{H}_{0}$ & $\mathbf{H}_{\mathrm{e}}$ & $\mathbf{H}_{0}$ & $\mathbf{H}_{\mathrm{e}}$ & $\mathbf{H}_{0}$ & $\mathbf{H}_{\mathrm{e}}$ & & \\
\hline $\mathbf{B}$ & V16 & 0.00 & 0.16 & 0.00 & 0.48 & 0.00 & 0.83 & 0.00 & 0.30 & 0.00 & 0.65 & 0.08 & 0.44 & 0.00 & 0.16 & 0.01 & 0.43 \\
\hline & V22 & 0.00 & 0.00 & 0.00 & 0.16 & 0.00 & 0.83 & 0.00 & 0.48 & 0.00 & 0.56 & 0.00 & 0.56 & 0.00 & 0.00 & 0.00 & 0.37 \\
\hline & V29 & 0.00 & 0.16 & 0.00 & 0.30 & 0.00 & 0.93 & 0.00 & 0.53 & 0.00 & 0.53 & 0.00 & 0.80 & 0.08 & 0.08 & 0.01 & 0.47 \\
\hline $\mathbf{H}$ & V1 & 0.00 & 0.30 & 0.00 & 0.43 & 0.00 & 0.40 & 0.00 & 0.00 & 0.00 & 0.43 & 0.00 & 0.44 & 0.00 & 0.30 & 0.00 & 0.33 \\
\hline H & V17 & 0.00 & 0.00 & 0.00 & 0.40 & 0.00 & 0.78 & 0.00 & 0.20 & 0.00 & 0.72 & 0.16 & 0.43 & 0.00 & 0.30 & 0.02 & 0.41 \\
\hline & V6 & 0.00 & 0.00 & 0.33 & 0.61 & 0.00 & 0.00 & 0.0 & 0.00 & 0.00 & 0.60 & 0.00 & 0.00 & 0.00 & & & 0.16 \\
\hline & V9 & 0.00 & 0.00 & 0.16 & 0.37 & 0.00 & 0.30 & 0.00 & 0.00 & 0.00 & 0.77 & 0.00 & 0.00 & 0.00 & 0.00 & 0.02 & 0.20 \\
\hline & V18 & 0.00 & 0.00 & 0.00 & 0.40 & 0.00 & 0.86 & 0.00 & 0.48 & 0.00 & 0.69 & 0.08 & 0.6 & 0.00 & 0.00 & 0.01 & 0.45 \\
\hline & V26 & 0.00 & 0.50 & 0.00 & 0.59 & 0.00 & 0.31 & 0.00 & 0.16 & 0.00 & 0.67 & 0.08 & 0.08 & 0.00 & 0.00 & 0.01 & 0.31 \\
\hline $\begin{array}{l}\text { Mean per locus } \\
\text { across landraces }\end{array}$ & - & 0.00 & 0.12 & 0.05 & 0.42 & 0.00 & 0.58 & 0.00 & 0.24 & 0.00 & $\begin{array}{r}0.62 \\
0.00\end{array}$ & 0.04 & 0.38 & 0.009 & $\begin{array}{l}0.09 \\
0.09\end{array}$ & $0.01 \S$ & 0.35I \\
\hline Total $\mathbf{H}_{\mathrm{T}} \#$ & - & & 0.13 & & 0.52 & & 0.86 & & 0.49 & & 0.90 & & 0.57 & & 0.09 & & $0.51 \dagger \dagger$ \\
\hline
\end{tabular}

$\dagger$ Observed heterozygosity per landrace and per locus.

†xpected heterozygosity per landrace and per locus.

$\S$ Average observed heterozygosity within landrace across all loci.

II Average expected heterozygosity within landrace across all loci.

\# Total expected heterozygosity per locus across all individuals (independent of landrace).

$\dagger \dagger$ Total expected heterozygosity across all loci and across all individuals (independent of landrace).

sity $\left(\mathrm{H}_{\mathrm{T}}\right)$ averaged 0.51 across all individuals across all analyzed loci. In general, the populations collected in the agroecological Zones B, F, and $\mathrm{H}$ showed higher within-population gene diversity averaged across all loci than Zone I.

\section{Field Results}

The ANOVA showed that the agroecological zones where the landraces were collected and the experimental sites had a great impact on the majority of the traits studied. Interactions between these factors were also significant for some traits (100-seed weight, leaf surface area, and growth habit). In addition, significant differences among landraces within agroecological zones were found for growth habit and phenological traits (days to flowering and days to physiological maturity).

Landraces from the agroecological Zone B performed better in terms of yield than landraces from the agroecological Zone I (Table 6). The landraces from the agroecological Zone B were characterized by both longer and wider pods compared with landraces from Zone I, and they had the most rapid days to flowering and maturity of the landraces studied. Landraces from the agroecological Zone $\mathrm{H}$ tended to have the longest stem length. No variation in the proportion of plants showing either of the variants of wing or standard color was observed among agroecological zones.

Differentiation of landraces within the respective agroecological zones occurred for phenological traits, standard color, and growth habit (Table 7). There was a clear differentiation in earliness between the landraces collected in Zone $\mathrm{H}$, and also to some extent between landraces from Zone I. Furthermore, the landraces collected in Zone $\mathrm{H}$ had a clear differentiation in the proportion of plants with an indeterminate bush (type II) growth habit and color of the standard.

Growing conditions were much poorer at San Pedro than at San Marcos, which resulted in a significant reduction of growth, as reflected by reduced stem length and leaf surface area and total bean yield, which was $26 \%$ lower in San Pedro (data not shown). With the exception of 100-seed weight, all yield components were lower at San Pedro compared with San Marcos. With regard to wing and standard petal color, the predominant variants were white and white with pink, respectively, and no significant differences between sites in the proportions of plants for these variables were observed.

Although there was a tendency for seed weight from all landraces to be greater when grown at San Pedro than when grown at San Marcos, only seed weight for landraces from the agroecological Zone $\mathrm{H}$ was significantly greater (Table 8). At San Pedro, no difference between landraces from different agroecological zones was found in terms of leaf surface area at flowering, while at San Marcos landraces from Zone I had the largest leaflets. Landraces collected in Zone H showed fewer plants with an indeterminate bush (type II) growth habit as compared with semivining (type III growth

Table 6. Effect of agroecological zones on agronomic, morphological, qualitative, and phenological traits of nine red-seeded Nicaraguan common bean landraces.

\begin{tabular}{|c|c|c|c|c|c|c|c|}
\hline \multirow[b]{2}{*}{$\begin{array}{l}\text { Agroecological } \\
\text { zone }\end{array}$} & \multirow[b]{2}{*}{$\frac{\text { Agronomic trait }}{\text { Yield }}$} & \multicolumn{3}{|c|}{ Morphological traits } & \multicolumn{3}{|c|}{ Phenological traits } \\
\hline & & $\begin{array}{c}\text { Pod } \\
\text { length }\end{array}$ & $\begin{array}{c}\text { Pod } \\
\text { width }\end{array}$ & $\begin{array}{c}\text { Stem } \\
\text { length }\end{array}$ & $\begin{array}{c}\text { Flowering } \\
\text { initiation }\end{array}$ & $\begin{array}{c}\text { Days to } \\
\text { flowering }\end{array}$ & $\begin{array}{c}\text { Physiological } \\
\text { maturity }\end{array}$ \\
\hline & $\mathbf{k g ~ h a}^{-1}$ & $\longrightarrow$ & $-\mathbf{c m}$ & - & 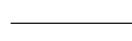 & $-\mathbf{D A P} \dagger$ & \\
\hline B & $1127 a \ddagger$ & 10.2ab & $0.89 \mathrm{a}$ & 74.6b & $29 b$ & 31c & $55 c$ \\
\hline $\mathbf{F}$ & 1069abc & 10.1abc & $0.84 b c$ & 81.4ab & $29 b$ & 31c & 58ab \\
\hline $\mathbf{H}$ & 1063ab & $10.3 a$ & $0.87 a b$ & $90.7 a$ & 30a & 33a & $60 a$ \\
\hline I & $917 \mathrm{c}$ & $9.7 \mathrm{c}$ & $0.81 c$ & 76.4ab & 30a & 32b & $\mathbf{5 7 b}$ \\
\hline
\end{tabular}

$\uparrow$ Days after planting.

\$ Letters in the same column represent mean separation by Tukey at the $5 \%$ level. 
Table 7. Phenological and qualitative traits of nine red-seeded Nicaraguan common bean landraces.

\begin{tabular}{|c|c|c|c|c|c|c|c|c|}
\hline \multirow[b]{3}{*}{$\begin{array}{l}\text { Agroecological } \\
\text { zone }\end{array}$} & \multirow[b]{3}{*}{ Landrace } & \multirow{2}{*}{\multicolumn{3}{|c|}{ Phenological traits }} & \multicolumn{4}{|c|}{ Qualitative traits } \\
\hline & & & & & \multicolumn{3}{|c|}{ Standard color } & \multirow{2}{*}{$\begin{array}{l}\text { Growth habit } \\
\text { indeterminate } \\
\text { bush, type II }\end{array}$} \\
\hline & & $\begin{array}{l}\text { Initiation of } \\
\text { flowering }\end{array}$ & $\begin{array}{c}\text { Days to } \\
\text { flowering }\end{array}$ & $\begin{array}{c}\text { Physiological } \\
\text { maturity }\end{array}$ & White & White-pink & Pink & \\
\hline & & & - DAP & - & 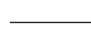 & - no. - & - & $\%$ \\
\hline B & V16 & 29 & 31 & 55 & 1 & 5 & 4 & 81.3 \\
\hline B & V22 & 29 & 31 & 55 & 0 & 5 & 5 & 73.8 \\
\hline $\mathbf{F}$ & V29 & 29 & 31 & 58 & 2 & 4 & 4 & $\mathbf{7 3 . 4}$ \\
\hline $\mathbf{H}$ & V1 & 32 & 35 & 66 & 9 & 1 & 0 & 47.5 \\
\hline $\mathbf{H}$ & V17 & 28 & 31 & 54 & 0 & 5 & 5 & 80.0 \\
\hline I & V6 & 30 & 33 & 59 & 2 & 8 & $\mathbf{0}$ & 86.3 \\
\hline I & V9 & 31 & 32 & 57 & 3 & 7 & 0 & 86.3 \\
\hline I & V18 & 28 & 32 & 58 & 2 & 8 & 0 & 82.5 \\
\hline I & V26 & 30 & 32 & 56 & 2 & 8 & o & 78.8 \\
\hline
\end{tabular}

habit) when grown at San Pedro than when grown at San Marcos.

\section{DISCUSSION}

The results show that the pattern of genetic diversity in the landraces studied depended on whether molecular or phenotypic markers were used. This finding suggests that the state of genetic diversity in landraces may be better described when different markers are used in a complementary manner. In our work, for example, microsatellites were ideal markers for detecting DNA polymorphism in the closely related but somewhat divergent genotypes while phenotypic markers allowed us to measure variation of adaptive traits among landraces from different agroecological zones.

\section{Variation among Agroecological Zones}

A specific pattern of geographic distribution of genetic diversity was not observed based on the molecular marker data for the landraces from the different agroecological zones, but there was a pattern based on phenotypic traits. This finding did not allow us to categorically accept or reject our second hypothesis. The contrast between the supposedly selectively neutral or near-neutral nature of microsatellites (Jarne and Lagoda, 1996; Li et al., 2000) and the adaptive value of phenotypic traits (Hill et al., 1998) might in part explain this apparent discrepancy. As pointed out by Lewontin (1984), the power of a statistical test to detect differences between quantitative characters is much higher than for polymorphic neutral or near-neutral genes. Considering that we have few polymorphic microsatellite loci in this study, we therefore refrain from giving any biological explana- tion to the observed discrepancy in geographic pattern between molecular and phenotypic markers.

We hypothesize that phenotypic traits are subject to both natural and artificial selection since environmental conditions and farmers' selection criteria lead to divergence between landraces. The clearly discernible differences in yield, morphological traits, and phenology observed among the nine common bean landraces from different agroecological zones supports this hypothesis. These results are in agreement with results obtained by Martin and Adams (1987a), Escribano et al. (1997), and Rodiño et al. (2001) for bean landrace collections in Africa and Europe. In Nicaragua, the environments where the common bean is cultivated are quite heterogeneous and show differences in altitude, temperature, rainfall, and edaphic conditions. Farm size, smallholder wealth, and consumer preferences can also vary among agroecological zones. As a result, the landraces studied here could have been subjected to different selection pressures, which in turn could have resulted in their differentiation.

\section{Variation among Landraces within Agroecological Zones}

The partitioning of the total genetic variation between landraces and agroecological zones by molecular markers indicated that a considerable part of the variation was attributable to differences among landraces within agroecological zones. A similar trend was observed for the phenological and qualitative traits. Therefore, we had to reject our third hypothesis, which claimed that the differentiation of common bean landraces was low.

There are several possible reasons for the genetic differentiation of the landraces. The fact that there was

Table 8. Effect of site by agroecological zone interaction on 100-seed weight, leaf surface area, and growth habit of nine red-seeded Nicaraguan common bean landraces.

\begin{tabular}{|c|c|c|c|c|c|c|}
\hline \multirow[b]{2}{*}{$\begin{array}{l}\text { Agroecological } \\
\text { zone }\end{array}$} & \multicolumn{3}{|c|}{ San Marcos } & \multicolumn{3}{|c|}{ San Pedro } \\
\hline & $\begin{array}{l}\text { 100-seed } \\
\text { weight }\end{array}$ & $\begin{array}{c}\text { Leaf surface } \\
\text { area }\end{array}$ & $\begin{array}{l}\text { Indeterminate } \\
\text { bush, type II }\end{array}$ & $\begin{array}{l}\text { 100-seed } \\
\text { weight }\end{array}$ & $\begin{array}{c}\text { Leaf surface } \\
\text { area }\end{array}$ & $\begin{array}{c}\text { Indeterminate } \\
\text { bush, type II }\end{array}$ \\
\hline & g & $\mathrm{cm}^{2}$ & $\%$ & g & $\mathbf{c m}^{2}$ & $\%$ \\
\hline B & 18.1ab $\dagger$ & $51.4 b$ & $71.3 \mathrm{a}$ & $19.8 b$ & $40.6 a$ & 83.8a \\
\hline $\mathbf{F}$ & $16.5 \mathrm{bc}$ & 57.0ab & $70.0 a$ & $18.8 b$ & 33.3a & $77.5 a$ \\
\hline $\mathbf{H}$ & $18.8 \mathrm{a}$ & $54.1 b$ & $76.3 \mathrm{a}$ & $22.0 \mathrm{a}$ & $34.4 a$ & 51.3b \\
\hline I & $15.3 \mathrm{c}$ & $64.2 \mathrm{a}$ & 83.8a & $15.9 \mathrm{c}$ & $36.5 a$ & 83.1a \\
\hline
\end{tabular}

$\uparrow$ Letters in the same column represent mean separation by Tukey at the $5 \%$ level. 
no detectable differentiation between agroecological zones in the case of molecular markers suggests that the differentiation of landraces and populations within landraces is because of founder effect. Another could be the predominantly self-pollinated mating system of the common bean (Graham and Ranalli, 1997), which causes low rates of gene flow among populations, which in turn results in a spatial differentiation as was pointed out by Hill et al. (1998).

In the case of growth habit and phenological traits, it is possible that landrace differentiation has resulted from a high level of human selection pressure focused toward adapting the landraces to new environments or cropping systems. Meanwhile, variation in standard petal color would reflect natural rather than human selection and could be explained by indirect selection of other traits or groups of traits.

\section{Variation within Landraces}

In the present report, almost two thirds of the variation determined at molecular level was distributed within landraces. This variation was evident in the high proportion of allelically different homozygous individuals for the loci analyzed, which in turn resulted in high gene diversity values within the landraces. Similar results have also been reported at the phenotypic level in common bean, indicating that landraces in this crop tend to be heterogeneous populations (Martin and Adams 1987a, 1987b; Tapia and Camacho, 1988; Briand et al., 1998).

In general, the observed heterozygosity within landraces averaged across all loci was quite low (0.01), which is in agreement with outcrossing values reported in the literature (Martin and Adams 1987a; Ibarra-Perez et al., 1997). Common bean is a predominantly self-pollinated crop (Graham and Ranalli, 1997); however, moderate to high levels of outcrossing have been reported (Wells et al., 1988; Gepts, 1993). Although most of the individuals were homozygous for most loci, the higher frequency of heterozygous individuals in several of the landraces from the agroecological Zone I suggests that outcrossing had occurred at the farm level and that gene flow had occurred between diverse individuals within the landrace or between adjacent landraces from neighboring farms. The incorporation of new alleles and higher outcrossing rates in these landraces could have been the result of contrasting environmental conditions within the zone, short distances between fields sown with different landraces, a high frequency of pollinating insects, or particular flower characteristics of the landraces.

\section{Site Effects}

The landraces in our field study were evaluated in two contrasting bean production environments; one with ideal conditions and the other with poor conditions more typical of where farmers cultivate their beans. The fact that some traits were only expressed at one of the sites shows the need for multilocation evaluation of landraces, and consequently we rejected our last hypothesis. In particular, landraces from agroecological
Zone $\mathrm{H}$, which cover a large range of elevations and was perhaps the most differentiated of the zones studied, showed specific adaptation. These results are in agreement with several authors who indicate that estimates of genetic diversity within and between populations often depend on experimental location (Escribano et al., 1997; Newbury and Ford-Lloyd, 1997; Pham and Van Hintum, 2000). Pérez de la Vega (1996) also indicates that adaptive traits are more easily observable in less-favorable environments than favorable ones.

\section{CONCLUSIONS}

Molecular and phenotypic markers complemented each other, and use of both allowed a more complete description of the level and pattern of genetic diversity of the landraces studied. The observed genetic structure suggests that sampling for genetic resources of common beans in Nicaragua should be stratified with respect to agroecological zones to cover the effects of adaptation, and from several farmers within zones to minimize the effects of random drift.

\section{ACKNOWLEDGMENTS}

We thank the Swedish International Development Cooperation Agency (SIDA) for the financial support of this work; Nicaraguan farmers, CIAT, and REGEN for providing the plant material; and the staff of Germplasm Characterization Laboratory of CIAT and Dr. Martin Lascoux for comments on the manuscript and help in data analysis. We are also grateful to Eleana Gaitán-Solís of the Unit of Biotechnology, CIAT, for providing some of the microsatellite markers.

\section{REFERENCES}

Beebe, S., P.W. Skroch, J. Tohme, M.C. Duque, F. Pedraza, and J. Nienhuis. 2000. Structure of genetic diversity among common bean landraces of middle American origin based on correspondence analysis of RAPD. Crop Sci. 40:264-273.

Bisby, F.A. 1995. Characterization of biodiversity. p. 21-106. In V.H. Heywood and R.T. Watson (ed.) Global biodiversity assessment. United Nations Environment Programme, Cambridge Univ. Press, Cambridge.

Blair, M.W., F. Pedraza, H.F. Buendía, E. Gaitán-Solís, S.E. Beebe, P. Gepts, and J. Tohme. 2003. Development of a genome-wide anchored microsatellite map for common bean (Phaseolus vulgaris L.). Theor. Appl. Genet. 107:1362-1374.

Bretting, P.K., and M.P. Widrlechner. 1995. Genetic markers and plant genetic resource management. Plant Breed. Rev. 13:11-71.

Briand, L., A.E. Brown, J.M. Lenné, and D.M. Teverson. 1998. Random amplified polymorphic DNA variation within and among bean landrace mixtures (Phaseolus vulgaris L.) from Tanzania. Euphytica 102:371-377.

CIAT. 2002. Annual report. Biotechnology Unit, CIAT, Cali, Colombia.

Dellaporta, S.L., J. Wood, and J.R. Hicks. 1983. A plant DNA minipreparation. Version II. Plant Mol. Biol. 1:19-21.

Engels, J.M.M., and B. Visser. 2000. Strategies and methodologies in genetic diversity conservation. p. 26-31. In C. Almekinders and W. De Boef (ed.) Encouraging diversity. The conservation and development of plant genetic resources. Intermediate Technology Publ., London.

Escribano, M.R., M. Santalla, and A.M. De Ron. 1997. Genetic diversity in pod and seed quality traits of common bean populations from northwestern Spain. Euphytica 93:71-81.

Frankel, O.H., A.H.D. Brown, and J.J. Burdon. 1995. The conservation of plant biodiversity. Cambridge Univ. Press, Cambridge.

Gaitán-Solís, E., M.C. Duque, K.J. Edwards, and J. Tohme. 2002. 
Microsatellite repeats in common bean (Phaseolus vulgaris L.): Isolation, characterization, and cross-species amplification in Phaseolus ssp. Crop Sci. 42:2128-2136.

Gepts, P. 1993. The use of molecular and biochemical markers in crop evolution studies. Evol. Biol. 27:51-94.

Gepts, P., and D. Debouck. 1991. Origin, domestication, and evolution of common bean (Phaseolus vulgaris L.). p. 7-53. In A. Van Schoonhoven and O. Voysest (ed.) Common beans: Research for crop improvement. CABI, Wallingford, UK, and CIAT, Cali, Colombia.

Gonzalez, D.O., N. Palacios, G. Gallego, and J. Tohme. 1995. Protocolo para marcadores moleculares. Unidad de Biotecnología. CIAT, Cali, Colombia.

Goudet, J. 2002. FSTAT: A program to estimate and test gene diversities and fixation indices. v. 2.9.3.2. [Online]. Available at: http:// www.unil.ch/izea/softwares/fstat.html (cited 5 Apr. 2002; verified 19 Feb. 2004). Institut d'Ecologie, Laboratoire de Zoologie, Lausanne, Switzerland.

Graham, P.H., and P. Ranalli. 1997. Common Bean (Phaseolus vulgaris L.). Field Crop Res. 53:131-146.

Hill, J., H.C. Becker, and P.M.A. Tigerstedt. 1998. Quantitative and ecological aspects of plant breeding. Chapman and Hall, London.

Ibarra-Perez, F.J., B. Ehdaie, and J. Giles Waines. 1997. Estimation of outcrossing rate in common bean. Crop Sci. 37:60-65.

Islam, F.M.A., K.E. Basford, R.J. Redden, A.V. Gonzalez, P.M. Kroonenberg, and S. Beebe. 2002. Genetic variability in cultivated common bean beyond the two major gene pools. Genet. Resour. Crop Evol. 49:271-283.

Jarne, P., and P.J.L. Lagoda. 1996. Microsatellites, from molecules to populations and back. Trends Ecol. Evol. 11:424-429.

Karp, A., S. Kresovich, K.V. Bhat, W.G. Ayad, and T. Hodgkin. 1997. Molecular tools in plant genetic resources conservation: A guide to the technologies. Bull. No. 2. Int. Plant Genetic Resources Inst., Rome.

Lewontin, R.C. 1984. Detecting population differences in quantitative characters as opposed to gene frequencies. Am. Nat. 123:115-124.

Li, C.D., B.G. Rossnagel, and G.J. Scoles. 2000. The development of oat microsatellite markers and their use in identifying among Avena species and oat cultivars. Theor. Appl. Genet. 101:1259-1268.

Llano, A., A. Viana, and R. Munguía. 1998. Perfil de la producción de frijol en Nicaragua. CENIA-PROFRIJOL, Inst. Nicaragüense de Tecnología Agropecuaria, Managua, Nicaragua.

Marín, E. 1990. Zonas agroclimáticas de Nicaragua. Unidad de estudios territoriales. Ministerio Agropecuario y Forestal, Managua, Nicaragua.

Martin, G.B., and M.W. Adams. 1987a. Landraces of Phaseolus vulgaris (Fabaceae) in northern Malawi. I. Regional variation. Econ. Bot. 41:190-203.

Martin, G.B., and M.W. Adams. 1987b. Landraces of Phaseolus vulgaris (Fabaceae) in northern Malawi. II. Generation and maintenance of variability. Econ. Bot. 41:204-215.

Maxted, N., B.V. Ford-Lloyd, and J.G. Hawkes, 1997. Complementary conservation strategies. p. 15-39. In N. Maxted et al. (ed.) Plant genetic conservation: The in situ approach. Chapman and Hall, London.

Muñoz, G., G. Giraldo, and J.F. De Soto. 1993. Descriptores varietales: Arroz, maíz, frijol y sorgo. Publ. 177. CIAT, Cali, Colombia.

Nei, M. 1987. Molecular evolutionary genetics. Columbia Univ. Press, New York.

Newbury, H.J., and B.V. Ford-Lloyd. 1997. Estimation of genetic diversity. p. 192-206. In N. Maxted et al. (ed.) Plant genetic conservation: The in situ approach. Chapman and Hall, London.

Pérez de la Vega, M. 1996. Plant genetic adaptedness to climatic and adaphic environment. Euphytica 92:27-38.

Pham, J., and T. Van Hintum. 2000. Genetic diversity and agroecosystems. p. 8-14. In C. Almekinders and W. De Boef (ed.) Encouraging diversity. The conservation and development of plant genetic resources. Intermediate Technology Publ., London.

Qualset, C.O., A.B. Damania, A.C.A. Zanatta, and S.B. Brush. 1997. Locally based crop plant conservation. p. 160-175. In N. Maxted et al. (ed.) Plant genetic conservation: The in situ approach. Chapman and Hall, London.

Raymond, M., and F. Rousset. 2001. Genepop on the Web [Online]. Available at http://wbiomed.curtin.edu.au/genepop (cited 7 May 2001; modified 2 Feb. 2004; verified 19 Feb. 2004). Laboratiore de Genetique et Environment, Montpellier, France.

Rodiño, A.P., M. Santalla, I. Montero, P.A. Casquero, and A.M. De Ron. 2001. Diversity of common bean (Phaseolus vulgaris L.) germplasm from Portugal. Genet. Resour. Crop Evol. 48:409-417.

SAS Institute. 1997. The SAS system for windows. Release 6.12. SAS Inst., Cary, NC.

SAS Institute. 2000. JMP statistics and graphics guide. v. 4. SAS Inst., Cary, NC.

Schneider, S., D. Roessli, and L. Excoffier. 2000. Arlequin. Version 2.000 [Online]. Available at http://anthro.unige.ch/arlequin (posted 15 June 1996; cited 10 May 2001; verified 19 Feb. 2004). Dep. of Anthropology, Univ. of Geneva, Geneva, Switzerland.

Singh, S.P., J.A. Gutiérrez, A. Molina, C. Urrea, and P. Gepts. 1991. Genetic diversity in cultivated common bean: II. Marker-based analysis of morphological and agronomic traits. Crop Sci. 31:23-29.

Soleri, D., and S.E. Smith. 1995. Morphological and phenological comparisons of two hopi maize varieties conserved in situ and ex situ. Econ. Bot. 49:56-77.

Tapia, H., and A. Camacho. 1988. Manejo integrado de la producción de frijol basado en labranza cero. Deutsche Gesellschaft für Technische Zusammenarbeit GmbH, Eschborn, Managua, Nicaragua.

Weir, B.S., and C.C. Cockerham. 1984. Estimating F-statistics for the analysis of population structure. Evolution 38:1358-1370.

Wells, W.C., W.H. Isom, and J.G. Waines. 1988. Outcrossing rates of six common bean lines. Crop Sci. 28:177-178.

Yu, K., S.J. Park, and V. Poysa. 1999. Abundance and variation of microsatellite DNA sequences in beans (Phaseolus and Vigna). Genome 42:27-34. 